\title{
二重ブロックを用いた動き補償予測方式
}

正会員 鈴 木 芳 典 $^{\dagger}$, 正会員 伊 東 晋 ${ }^{\dagger}$ 名誉会員 宇都宮 敏 男

\section{A Motion Compensated Prediction Method Using Dual Blocks}

\author{
Yoshinori Suzuki ${ }^{\dagger}$, Susumu Itoh $^{\dagger}$ and Toshio Utsunomiya ${ }^{\dagger}$
}

あらまし ブロック境界部の予測誤差電力を低減し得る新しいブロックマッチング法を提案する. 半ブロック分だけ互いに位置をずらした 2 種類のブロック分割に基づいて各々の予測画像を作成し た後，これらを加重平均することで予測効率を改善すると共に符号化レートを低減した。

\section{1. ま がき}

近年, 動画像符号化においては動き補償 (MC) 予 測が必須の技術として用いられている．MC 予測には 従来より様々な手法が提案されているが, 演算量が比 較的少なくノイズの影響を受けにくいブロックマッチ ング (BM) 法が主流になっている.しかし，BM 法は 画像の内容とは無関係に分割された正方形あるいは長 方形のブロックを単位とした独立処理であり，隣接ブ ロック間で動き量が互いに異なる場合にはブロック境 界に沿って歪みが発生する.このブロック歪みを抑压 し，ブロック境界部で増大する予測誤差電力を低減す るために，本論文では従来のブロック分割に基づいた BM 法を適用すると共に，これとは半ブロック分だけ 位置をずらした第 2 のブロック分割を行い，これらの ブロックについても BM 法を適用する.このようにし て得られた 2 種類の予測画像を, 各々のブロックにお ける各画素の相対位置に応じた重み係数を用いて加重 平均することにより, 予測誤差電力の分布が均一化さ れた最終的な予測画像を作成する。この提案方式 (二 重ブロックマッチング法と呼ぶ）では，第 2 の予測画 像を作成するために新たな動べクトル情報が必要とな るが, 予測誤差信号の符号化まで含めたトータルの符
号化性能は向上することを, シミュレーションによっ て明らかにしている.

\section{2. 二重ブロックマッチング法 ${ }^{1)}$}

\section{1 ベース予測画像の作成}

本論文では, MPEG-2 のフィールド構造における予 測モード(フィールド予測, $16 \times 8$ フィールド予測, デュアルプライム予測 $)^{2)}$ を基準方式としており, 図 1 に示すようにベースブロックのマッチングによる第 1 の予測画像 (ベース予測画像) の作成時には，この MPEG-2 の予測方式を使用している. ただし，今回は 二重ブロックマッチング法(二重 BM 法)の基本性能を 明らかにすることが目的であるため，双方向予測は使 用しない低遅延モードを採用している，また，動べク トルの探索範囲は水平・垂直両方向とも $-16 \sim+15.5$ としており, ブロックマッチングにより検出された動 ベクトルはMPEG-2 に準拠した方式で伝送される.

\section{2 シフト予測画像の作成}

二重 BM 法は 2 種類の予測画像が互いの予測性能の 低い領域，すなわちブロック境界部を補い合うことに より予測効率の改善を図る手法である.したがって, これらの予測画像は同程度の品質を保っている必要が ある.また，第 2 の予測画像 (シフト予測画像)はシフ

キーワード : MPEG-2, ブロックマッチング, 予測誤差電力, 二重ブロック

1994 年 10 月 18 日, 第 9 回画像符号化シンポジウム (PCSJ'94) で発表

1995 年 4 月 10 日受付, 1995 年 8 月 17 日再受付

†東京理科大学 理工学部 電気工学科 ( $\boldsymbol{T} 278$ 野田市山崎 2641, TEL 0471-24-1501)

$\dagger$ Faculty of Science and Technology, Science University of Tokyo (2641, Yamazaki, Noda-shi, Chiba 278, Japan) 


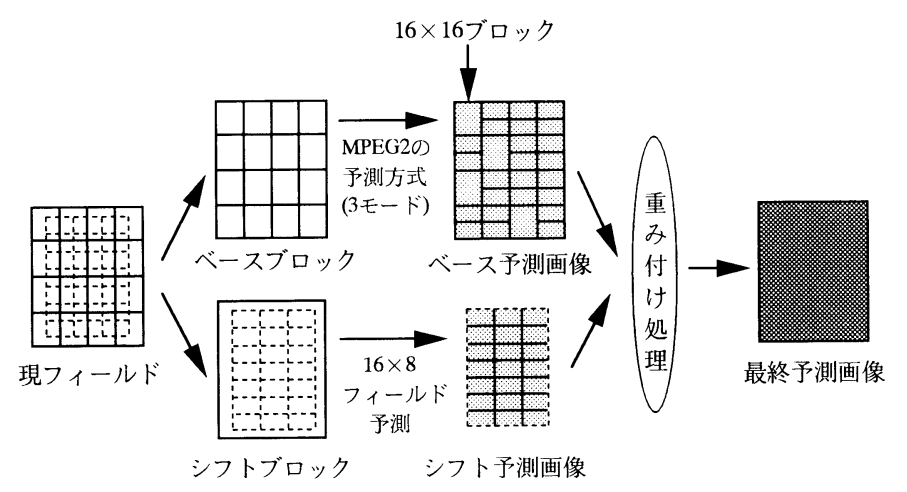

図 1 二重ブロックマッチング法

The block matching method based on dual blocks.

トブロックのマッチングにより作成されるが，それに 伴う演算量の増加を極力抑圧する必要がある．そこで 本論文では, ベースブロックの最小 $\mathrm{MC}$ ブロックサイ ズが $16 \times 8$ であることに着目し， シフトブロックの サイズをこれと同一の $16 \times 8$ に固定してシフト予測 画像の品質低下を防止すると共に, 各シフトブロック に対しては $16 \times 8$ フィールド予測のみを適用するこ とで演算量の大幅な増加を防止している.

なお，図 1 に示すようにシフトブロックのブロック 分割は原則としてベースブロックに対して半ブロック 分, すなわち 8 画素 $\times 4$ ラインだけずれており，各 ベースブロックの頂点がシフトブロックの中央部に位 置する構成となっている. また, シフト予測画像の作 成に要する動ベクトルの符号化レートを低減するため, その探索に際しては, 当該シフトブロックと互いに重 なりを持っている複数のベースブロックの動ベクトル の平均值を初期偏位ベクトルとし, 探索範囲をベース ブロックのそれの約半分 $(-8 \sim+7.5)$ に制限してい る. したがって, シフトブロックの動ベクトルについ ては, 上記の初期偏位ベクトルとの差分がコード数の 少ない符号表を用いて符号化される. またこの情報は, 当該シフトブロックと互いに重なりを持つベースブ ロックの中で, 右下に位置するブロックの動ベクトル に付随して伝送されるため, 各マクロブロックにおい て前方向動ベクトルが計 4 本まで伝送可能となるよう に, MPEG-2 の符号化アルゴリズムを修正している.

\section{3 最終予測画像の作成}

上記 2 種類の予測画像の同一位置における画素値 （予測值）を，適切な重み係数を用いて加重平均する ことにより最終予測画像を作成する. この重み係数 $f_{b}$ および $f_{s}$ は, 図 2 に示すように注目画素 $P$ のベース ブロックならびにシフトブロック内での相対位置のみ

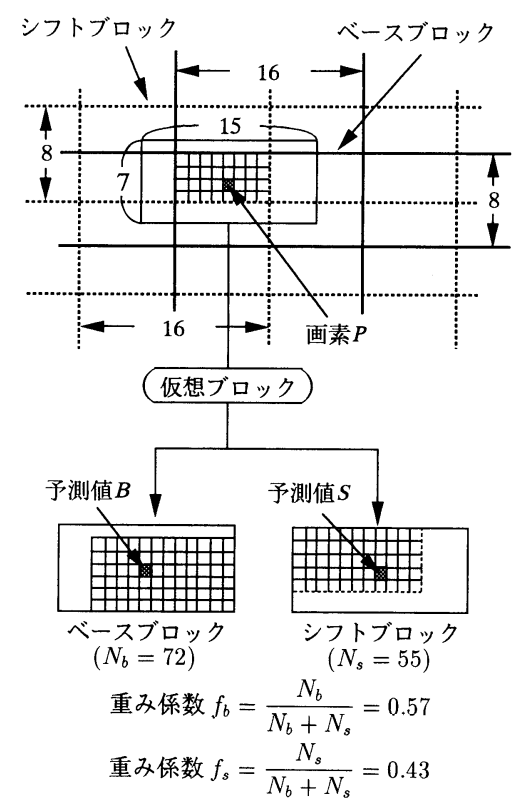

図 2 重み係数の算出法 Calculation of weighting factors.

から算出される.この際, 最小 MC ブロックサイズが $16 \times 8$ であることから, ブロック中央部の 4 画素にお いて重み係数が最大となるように, 15 画素 $\times 7$ ライン の仮想ブロックを考えて重み係数を算出している，具 体的にはまず，この仮想ブロックを画素 $P$ がその中 心に位置するように構成し, ベース予測画像およびシ フト予測画像に各々重ね合わせる. 次に, 画素 $P$ の 属するベースブロックと仮想ブロックとの間で, 互い に重なりを持っている画素数 $N_{b}$ をカウントする. ま たシフトブロックについても同様にして仮想ブロック と重なり合っている画素数 $N_{s}$ を求める. 2 つの重み 
係数 $f_{b}, f_{s}$ は, これらの $N_{b}, N_{s}$ を用いて図 2 のよ うにして算出され，この例では各々 $0.57,0.43$ になる. よって画素 $P$ の最終的な予測値は, $f_{b} \cdot B+f_{s} \cdot S$ と なり, 他の画素についても同様の計算を行うことで最 終予測画像が得られる.

ただし，以上の手順に従って算出された重み係数を ブロックを単位として整理すると, 数種類のパターン に集約される. したがって, 各画素に対してその都度 重み係数を算出する必要はなく, 実際にはブロックを 単位とした重み関数としてあらかじめ記憶されている. この重み関数は前述したように, ブロック中央部の 4 画素において最大值をとり, ブロック境界へ近づくに 従って減少していくため, この関数を用いた二重 BM 法では, 一方の予測画像のブロック境界部を他方の予 測画像のブロック中央部が補う形となり, 予測誤差電 力の分布が均一化された最終予測画像が得られる. ま た同様の理由により，最終予測画像ではブロック境界 部においても予測値の連続性が保たれるので, ブロッ ク歪みが大幅に低減される。すすなわち, 重み関数はブ ロック中央部から境界部に向かって単調减少する必要 があり, ベース予測画像とシフト予測画像の単純な平 均処理（すべての画素において $f_{b}=f_{s}=0.5$ とする 方式であり, 平均方式と呼ぶ) では, ブロック歪みの 低減効果が半減する。

\section{3. 特 性 評 価}

ITU-R 勧告 601 規格のディジタル動画像 Cheer Leaders, Mobile \& Calendar を 4:2:0 のフォーマッ トに変換した画像（各々 24 フィールド）を対象とし て，二重 BM 法のシミュレーションを行った．まず, 本方式の基本的な予測性能を明らかにするために，原 画像を参照画像として用いた際の予測䛊差電力を算 出した. 表 1 にはベースブロックの境界部と中央部に おける予測誤差電力を示す. ただし，ベースブロック の境界部とは各ベースブロックの境界から 2 画素以内 の距離にある領域を表している．また比較のために， ベース予測画像が最終的な予測画像となる従来方式, および平均方式の結果についても併せて示す.

表 1 より, 従来方式ではブロック境界部で予測誤差 電力が増大しているのに対し, 本方式ではその分布が かなり均一化されており，二重ブロック構造とした効 果が認められる．また，ブロック境界部のみならず中 央部においても, 従来方式に比較して予測誤差電力が 低減されていることがわかる，一方，本方式の平均方 式に対する利得はわずかである，これは，本方式の重 み関数が必ずしも最適化されていないためと考えられ
表 1 原画を参照画像とした際の予測誤差電力の 比較 ( $\mathrm{Y}$ 信号)

Comparison of the power of prediction errors for $\mathrm{Y}$ signals when regarding the original image as a refernce.

\begin{tabular}{c|c|c|c}
\hline \hline $\begin{array}{l}\text { Cheer } \\
\text { Leaders }\end{array}$ & $\begin{array}{c}\text { ブロックの } \\
\text { 境界部 }\end{array}$ & $\begin{array}{c}\text { ブロックの } \\
\text { 中央部 }\end{array}$ & 画面全体 \\
\hline 本方式 & 103 & 82.7 & 93.5 \\
\hline 従来方式 & 163 & 98.1 & 132 \\
\hline 平均方式 & 108 & 86.5 & 97.3 \\
\hline \hline \multicolumn{4}{|c}{} \\
\hline \hline $\begin{array}{c}\text { Mobile \& } \\
\text { Calendar }\end{array}$ & $\begin{array}{c}\text { ブロックの } \\
\text { 境界部 }\end{array}$ & $\begin{array}{c}\text { ブロックの } \\
\text { 中央部 }\end{array}$ & 画面全体 \\
\hline 本方式 & 141 & 131 & 135 \\
\hline 従来方式 & 197 & 161 & 178 \\
\hline 平均方式 & 141 & 132 & 136 \\
\hline
\end{tabular}

表 2 予測誤差電力 ( $\mathrm{Y}$ 信号) と符号化レート The power of prediction errors for $\mathrm{Y}$ signals and coding rates.

\begin{tabular}{|c|c|c|c|}
\hline \multirow{2}{*}{$\begin{array}{l}\text { Cheer } \\
\text { Leaders }\end{array}$} & \multirow{2}{*}{$\begin{array}{l}\text { Y 信号の予 } \\
\text { 測誤差電力 }\end{array}$} & \multicolumn{2}{|c|}{ 符号化レート (Mb/s) } \\
\hline & & 動ベクトル & 予測誤差信号 \\
\hline 本方式 & 113 & 0.781 & 4.37 \\
\hline 従来方式 & 152 & 0.413 & 5.10 \\
\hline \multirow{2}{*}{$\begin{array}{l}\text { Mobile \& } \\
\text { Calendar }\end{array}$} & \multirow{2}{*}{$\begin{array}{l}Y \text { 信号の予 } \\
\text { 測誤差電力 }\end{array}$} & \multicolumn{2}{|c|}{ 符号化レート（Mb/s） } \\
\hline & & 動ベクトル & 予測誤差信号 \\
\hline 本方式 & 170 & 0.621 & 7.24 \\
\hline 従来方式 & 217 & 0.320 & 8.15 \\
\hline
\end{tabular}

る. しかし, 両方式の予測画像を比較した結果, 平均 方式では依然としてブロック歪みが観測されるのに対 し，本方式ではほぼ完全に解消されていることを確認 している.

次に, 符号化レートも含めたトータルの性能を評 価するために，本方式および従来方式を MPEG-2 の MP@ML の予測部に組み入れた際のシミュレーショ ンを行った，ただし，本論文ではフィールド構造の低 遅延モードに符号化処理を限定すると共に, DCT 係 数の量子化ステップ幅は係数毎に一定值に固定した (quantizer_scale = 18). 表 2 には, 画面全体での予 測誤差電力と動ベクトルおよび DCT 係数の平均符号 化レートを示す，またフィールド毎の符号化特性を 図3に示す。

表 2 より，実際の符号化に適用した場合でも従来方 式に比較して予測誤差電力が大幅に低減されること が確認できる. その結果, 本方式では予測誤差信号の 符号化レートが削減され, 動ベクトルの符号化レー 卜の増加分を充分に補っていることがわかる.さらに 

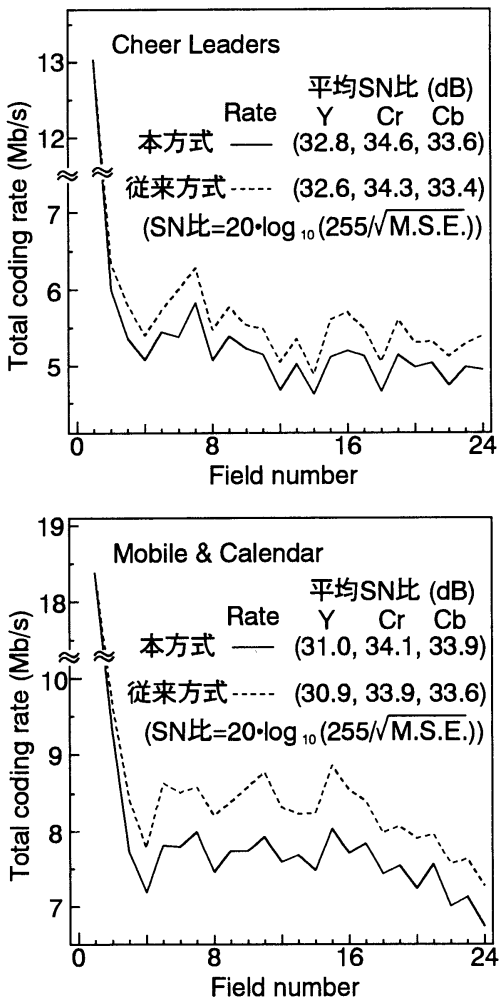

図 3 符号化特性

Coding performance.

図 3 より，いずれの画像についても本方式の方が優れ た特性を示すことが確認できる，すなわち，本論文で は DCT 係数の量子化ステップ幅を固定しているため, 両方式の平均 $S / N$ はほぼ一致すると共に, この傾 向はフィールド毎の $S / N$ についても全く同様に認 められた．これに対して，本方式のトータルの符号化 レートは従来方式よりも 6 8\%程度低減されている. なお，quantizer_scale を 18 より小さく（例えば 12 に）設定しても，本方式の符号化利得は変化しないこ とを確認している.

\section{4.むす び}

ブロック境界部の予測誤差電力を低減し得る新しい ブロックマッチング法を提案した．本方式では，互い のブロック境界部を補い合うようにして作成された 2 種類の予測画像を加重平均することにより, 予測誤差 電力の大幅な低減を実現している，したがって，動べ クトルの符号化レートは増加するものの, 予測誤差信 号の符号化レートが削減されるため, 従来方式よりも 優れた符号化特性を得ることができる．また，本方式 はブロック境界部で予測值を滑らかに接続するため, ブロック歪みをほぼ完全に解消することが可能である.

今後の課題としては, 動ベクトルの符号化レートの 削减, シフトブロックにおける適応予測の導入, 重み 関数の最適化, 双方向予測への拡張等が挙げられる.

\section{[参 考 文 献]}

1) 鈴木, 伊東, 宇都宮 : “オーバラップ 2 重ブロックマッチン グ法”, PCSJ'94, 5-3 (Oct. 1994)

2) ISO/IEC JTC1/SC29/WG11 N0702: "Information Technology -Generic Coding of Moving Pictures and Associated Audio", Draft International Standard (Mar. 1994)

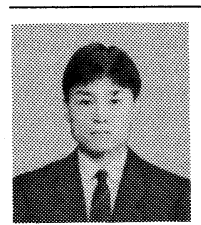

すずきよしのり

鈴木 芳典 平成 5 年, 東京理科大学理工 学部電気工学科卒業. 平成 7 年, 同大学大学 院修士課程修了。同年，(株）日立製作所に入 社. 在学中は, 画像の高能率符号化に関する 研究に従事. 正会員.

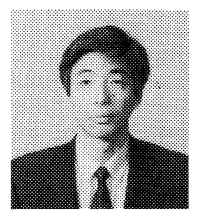

伊東晋 昭和 51 年, 東京大学工学 部電子工学科卒業. 昭和 56 年, 東京大学大学 院工学系研究科電子工学専攻博士課程修了. 同年より, 東京理科大学理工学部電気工学科 に勤務し, 現在, 同助教授. 画像処理, 生体 信号処理等の研究に従事. 工学博士. 正会員.

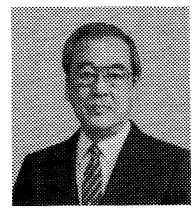

うつのみやとしお

宇都宮敏男 昭和 18 年, 東京大学第一工 学部電気工学科卒業. 大学院特別研究生を経 て, 23 年, 東大助教授. 36 年, 同教授. 57 年定年退職し, 東京理科大学理工学部電気工 学科教授. 電子回路お上び医用生体工学の教 育・研究に従事. 工学博士. 東大名誉教授. 名誉会員. 